surgery but also in those elderly and frail patients who still have their gall bladders in situ. ${ }^{15}$

Requests for reprints should be addressed to: Dr P B Cotton, Gastrointestinal Unit, The Middlesex Hospital, Mortimer Street, London W1N 8AA.

\section{References}

${ }^{1}$ Bateson MC, Boucher IAD. Prevalence of gall stones in Dundee: a necropsy study. $\mathrm{Br} \mathrm{Med} \mathcal{F} 1975$;iv:427-30.

2 Strohl EL, Diffenbaugh WG, Anderson RE. Biliary tract surgery in the aged patient. Geriatrics 1964;19:275-9.

${ }^{3}$ Glenn F, McSherry CK. Calculous biliary tract disease. Curr Probl Surg 1975; June: $1-38$.

4 Wenkert A, Robertson B. The natural course of gallstone disease. Gastroenterology 1966;50:376-81.

5 Spohn K, Fux HD, Mehnert U, Muller-Kluge M, Tewes G. Cholecystektomie und choledochotimie Taktik und Techniken. Langenbecks Arch Chir 1973;334:249-59.
${ }^{6}$ Vellacott KD, Powell PH. Exploration of the common bile duct. A comparative study. Br 7 Surg 1979;66:389-91.

${ }^{7}$ Cotton PB. Non-operative removal of bile duct stones by duodenoscopic sphincterotomy. Br $\mathcal{F}$ Surg 1980;67:1-5.

${ }^{8}$ Mazzariello RM. A fourteen year experience with non-operative instrument extraction of retained bile duct stones. World f Surg 1978;2:447-55.

9 Burhenne HJ. Non-operative instrument extraction of retained bile duct stones. World f Surg 1978;2:439-45.

${ }^{10}$ Cotton PB. Progress report ERCP. Gut 1977;16:316-41.

${ }^{11}$ Cotton PB, Mason RR, Burney PGJ. Trans-nasal bile duct catherisation after endoscopic sphincterotomy; a method for biliary drainage, perfusion and sequential cholangiography. Gut 1979;20:285-7.

12 Madden JW, Croker JR, Beynon GPJ. Septicaemia in the elderly. Postgraduate Med $\mathcal{f}$ (in press).

13 Witzel L, Wiederholt J, Wolbergs E. Dissolution of gallstones by perfusion with Capmul via a catheter introduced endoscopically into the bile duct. $N$ Engl f Med 1980;303:465.

14 Cotton PB, Vallon AG, Mason RR. Intraductal infusion of mono-octanoin for common duct stones. Lancet 1981;i:436-7.

15 Vallon AG, Cotton PB. Duodenoscopic sphincterotomy in patients with gallbladders. Gut 1981 ;22:A428.

(Accepted 25 fune 1981)

\title{
Role of local authority homes in the care of the dependent elderly: a prospective study
}

\author{
G MASTERTON，E M HOLLOWAY，G C TIMBURY
}

\begin{abstract}
A two-year prospective study of 11 local authority homes showed no increase in the degrees of behavioural disabilities or the prevalence of dependency or dementia among the residents. This finding, which differed from trends reported in other studies, was unlikely to be due to the design of the study and occurred in the absence of a co-ordinated service for the elderly. It was probably the effect of changes in the admission policy of the socialwork services and suggests that, in some parts of Britain at least, residential homes are no longer absorbing additional numbers of dependent or demented old people in need of institutional care.
\end{abstract}

\section{Introduction}

Studies $^{1-3}$ from different regions have reported that the population living in local authority homes is becoming increasingly like that in National Health Service geriatric and psychogeriatric long-stay units in terms of dependency and disability. Such studies, however, have relied entirely on staff ratings of functional disabilities, and only Wilkin $e t$ al $^{3}$ employed a prospective design (with a one-year follow-up). We therefore report the

\footnotetext{
University Department of Psychological Medicine, Glasgow G12 OAA

G MASTERTON, MB, MRCPSYCH, lecturer in psychological medicine E M HOLLOWAY, MB, CHB, medical assistant in geriatric psychiatry G C TIMBURY, FRCP (GLASG, ED), FRCPSYCH, dean of postgraduate medicine, Glasgow University
}

results of a two-year prospective study in which independent psychometric measurements were made as well as functional ratings.

\section{Subjects and method}

All 11 local authority homes (distributed in three social-work districts) within the catchment area of Gartnavel Royal Hospital, Glasgow, were included in the study. A total of 388 residents were assessed in 1978 and 383 in 1980, which represented inclusion rates of $96.0 \%$ and $95.8 \%$, respectively. The main reasons for not including some residents were illness, refusal, and being out, which occurred in roughly the same proportions in both surveys.

Independent assessments of each resident were made by a senior member of staff in the home and by a psychiatrist. Staff members assessed behavioural disabilities for each resident using the Shortened Stockton Geriatric Rating Scale. ${ }^{4}$ This 18 -item scale measures four factors of impairment-physical disability, apathy and inactivity, communication problems, and socially disruptive behaviour-which are combined to give a total disability score. The subject may also be assigned to a dependency grade, based on the total score, ranging from $\mathrm{A}$ (independent) to $\mathrm{E}$ (maximum dependency).

During a 20 -minute standard interview the psychiatrist assessed each resident using the Crichton Orientation Test $^{5}$ and the Modified Kew Test. ${ }^{6}$ To be diagnosed as demented a resident had to show both disorientation in the Crichton test and multiple deficits in the Kew test at levels in keeping with the diagnosis of dementia. To be classified as unimpaired the resident had to have normal results in both tests. A normal result in one test but not in the other placed the resident in an intermediate group termed "borderline dementia."

\section{Results}

The changes in the mean levels of behaviour disabilities were small and, except for the physical disability factor, all scores were decreased (table I). Grouping the residents into dependency grades based on their degree of functional disabilities showed that no change had occurred between 1978 and 1980 (table II). Psychometric ratings 
TABLE I-Total and factor average scores achieved with Shortened Stockton Geriatric Rating Scale

\begin{tabular}{cccccc}
\hline & $\begin{array}{c}\text { Physical } \\
\text { disability }\end{array}$ & $\begin{array}{c}\text { Apathy } \\
\text { inactivity }\end{array}$ & $\begin{array}{c}\text { Communication } \\
\text { difficulty }\end{array}$ & $\begin{array}{c}\text { Social } \\
\text { disturbance }\end{array}$ & $\begin{array}{c}\text { disability } \\
\text { score }\end{array}$ \\
\hline 1978 & $4 \cdot 39$ & 5.51 & 0.56 & 2.55 & $13 \cdot 01$ \\
1980 & 4.48 & 5.32 & 0.47 & $2 \cdot 42$ & 12.69 \\
\hline "Change & +2.1 & -3.4 & $-16 \cdot 1$ & $-5 \cdot 1$ & -2.5 \\
\hline
\end{tabular}

TABLE II-Dependency grades assessed with Shortened Stockton Geriatric Rating Scale. $(A=$ Independent $: E=$ maximum dependency)

\begin{tabular}{ccccccc}
\hline & A & B & C & D & E \\
\hline 1978 & 39 & 68 & 105 & 71 & 105 \\
1980 & 37 & 66 & 107 & 71 & 102 \\
\hline$\%$ Change & -0.4 & -0.3 & +0.8 & $+0 \cdot 2$ & -0.5
\end{tabular}

TABLE III-Psychometric state

\begin{tabular}{lccc}
\hline & Demented & Borderline & Not demented \\
\hline 1978 & 163 & 73 & 152 \\
1980 & 159 & 60 & 164 \\
\hline$\%$ Change & -0.5 & $-3 \cdot 1$ & $+3 \cdot 6$ \\
\hline
\end{tabular}

showed a $3 \%$ shift from borderline dementia to unimpaired, but the proportion of the population who were demented remained virtually unaltered at $41 \cdot 5 \%$ (table III).

\section{Discussion}

In contrast with trends shown in other studies, ${ }^{1-3}$ we found no evidence of increasing numbers of dependent residents being cared for within local authority homes for the elderly. Arguably the duration of our prospective study (two years) was too short to allow for change, yet Wilkin $e t a l^{3}$ followed up slightly more than half the number of residents that we studied, and for half the length of time, and concluded that their homes were caring for increasingly disabled elderly people.

Though precise figures for the area are not available, our study was carried out when the numbers of elderly in Glasgow as a whole were increasing. Over the same period within the geriatric psychiatry service of Gartnavel Royal Hospital substantial increases occurred in the number of referrals $(14 \%)$, day-hospital attenders $(62 \%)$, and holiday admissions $(63 \%)$, though admissions to the long-stay wards and discharges by death remained constant.

Nor can our findings be accounted for by the introduction of a fully co-ordinated district policy for the elderly, though liaison was sufficiently well established to allow this project to take place. Poor collaboration between the social services and health services (geriatric and psychogeriatric) has been identified on

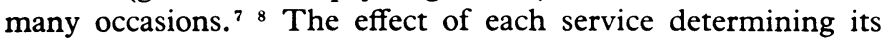
own selection and admission policies and being able to modify them unilaterally without reference to the other services was first observed in England in the early 1970s when the number of psychogeriatric long-stay admissions fell, apparently in response to well-publicised scandals in mental hospitals. ${ }^{9}$

The current dilemma faced by the social services as a result of the rapid increase in dependent elderly is whether to continue to admit old people with greatest dependency needs, on the basis that local authority homes are duty bound to tend those most in need of care (with the consequences discussed in the earlier studies $^{1-3}$ ), or to select those old people who require the level of care which maintains a manageable prevalence of disabilities in the home, as suggested by our findings.

Wherever the emphasis in policy is placed, the effect will be that many highly dependent old people who require the intensive nursing and medical supervision provided in the appropriate continuing-care units will not receive it-being either misplaced in local authority homes, or occupying beds in the acute wards of many specialties, ${ }^{10} 11$ or being maintained in the community by a system of shared care between the Health Service's day and domiciliary provisions and relatives or friends until such time as a bed in a long-stay ward becomes available. ${ }^{12}$

A policy of the selection panels for local authority residential care which rejects severely disabled old people is a realistic and desirable acknowledgment that the resources of their staff and buildings are finite. It may also expedite the funding and implementation of the appropriate types of continuing-care unit that the growing numbers of severely disabled elderly people require-for the remarkable tolerance of supporting relatives ${ }^{13}{ }^{14}$ and the willingness of social service staff to look after highly dependent old people are factors which have probably contributed to the serious delay.

We thank the district managers, supportive services officers, and residential home staff of Dumbarton, Clydebank, and Glasgow West districts of Strathclyde's social services for their support and cooperation with this project.

\section{References}

${ }^{1}$ Gilleard CJ, Pattie AH, Dearman G. Behavioural disabilities in psychogeriatric patients and residents of old people's homes. $f$ Epidemiol Community Health $1980 ; 34: 106-10$.

2 Gilleard CJ. The prevalence of incontinence in local authority homes for the elderly. Health Bull (Edinb) $1980 ; 38: 236-8$.

${ }^{3}$ Wilkin D, Mashiah T, Jolley DJ. Changes in the behavioural characteristics of elderly populations of local authority homes and long-stay hospital wards, 1976-7. Br Med F 1978;ii:1274-6.

${ }^{4}$ Pattie AH, Gilleard CJ. Manual for the Clifton Assessment Procedures for the Elderly (CAPE). Sevenoaks: Hodder and Stoughton, 1979.

5 Irving G, Robinson RA, McAdam W. The validity of some cognitive tests in the diagnosis of dementia. Br F Psychiatry 1970;117:149-56.

${ }^{6}$ Hare M. Clinical check list for diagnosis of dementia. Br Med $\mathcal{F} 1978$;ii : 266-7.

${ }^{7}$ Royal Commission on the National Health Service. $A$ service for patients. Cmnd 7615. London: HMSO, 1979.

${ }^{8}$ Scottish Home and Health Department. Report on services for the elderly with mental disability in Scotland. London: HMSO, 1979.

9 Shulman K, Arie T. A fall in the admission rate of the elderly to psychiatric hospitals. Br Med F 1978 ;i :156-8.

${ }^{10}$ McArdle C, Wylie JC, Alexander WD. Geriatric patients in an acute medical ward. Br Med f 1975 ;iv:568-9.

11 Strang IW, Boddy FA, Jennett B. Patients in acute surgical wards: a survey in Glasgow. Br Med 7 1977; :545-8.

12 Greene JG, Timbury GC. A geriatric psychiatry day hospital service: a five-ycar review. Age Ageing 1979;8:49-53.

13 Isaacs B. Geriatric patients: Do their families care ? $\mathrm{Br}$ Med $\mathcal{F} 1971$;iv: 282-6.

14 Sanford JRA. Tolerance of debility in elderly dependents by supporters at home : its significance for hospital practice. $\mathrm{Br}$ Med $\mathcal{F} 1975 ; \mathrm{iii}: 471-3$.

(Accepted 17fune 1981)

ARTICHOKES. The Latins call them Cinera, only our college calls them Artichocus. They are under the dominion of Venus, and therefore it is no marvel if they provoke lust, as indeed they do, being somewhat windy meat; and yet they stay the involuntary course of natural seed in man, which is commonly called nocturnal pollutions. And here I care not greatly if I quote a little of Galen's nonsense in his treatise of the faculties of nourishment. He saith, they contain plenty of choleric juice, (which notwithstanding I can scarcely believe,) of which he saith is engendered melancholy juice, and of that melancholy juice thin choleric blood. But, to proceed; this is certain, that the decoction of the root boiled in wine, or the root bruised and distilled in wine in an alembic, and being drank, purges by urine exceedingly. (Nicholas Culpeper (1616-54) The Complete Herbal, 1850.) 